\title{
Deposition and immersion-mode nucleation of ice by three distinct samples of volcanic ash
}

\author{
G. P. Schill ${ }^{1, \mathrm{a}}$, K. Genareau ${ }^{2}$, and M. A. Tolbert ${ }^{1}$ \\ ${ }^{1}$ Department of Chemistry and Biochemistry and Cooperative Institute for Research in Environmental Science, \\ University of Colorado, Boulder, CO, USA \\ ${ }^{2}$ Department of Geological Sciences, University of Alabama, Tuscaloosa, AL, USA \\ ${ }^{a}$ now at: Department of Atmospheric Sciences, Colorado State University, Fort Collins, CO, USA
}

Correspondence to: M. A. Tolbert (tolbert@ colorado.edu)

Received: 03 December 2014 - Published in Atmos. Chem. Phys. Discuss.: 16 January 2015

Revised: 20 May 2015 - Accepted: 15 June 2015 - Published: 10 July 2015

\begin{abstract}
Ice nucleation of volcanic ash controls both ash aggregation and cloud glaciation, which affect atmospheric transport and global climate. Previously, it has been suggested that there is one characteristic ice nucleation efficiency for all volcanic ash, regardless of its composition, when accounting for surface area; however, this claim is derived from data from only two volcanic eruptions. In this work, we have studied the depositional and immersion freezing efficiency of three distinct samples of volcanic ash using Raman microscopy coupled to an environmental cell. Ash from the Fuego (basaltic ash, Guatemala), Soufrière Hills (andesitic ash, Montserrat), and Taupo (Oruanui eruption, rhyolitic ash, New Zealand) volcanoes were chosen to represent different geographical locations and silica content. All ash samples were quantitatively analyzed for both percent crystallinity and mineralogy using X-ray diffraction. In the present study, we find that all three samples of volcanic ash are excellent depositional ice nuclei, nucleating ice from 225 to $235 \mathrm{~K}$ at ice saturation ratios of $1.05 \pm 0.01$, comparable to the mineral dust proxy kaolinite. Since depositional ice nucleation will be more important at colder temperatures, fine volcanic ash may represent a global source of cold-cloud ice nuclei. For immersion freezing relevant to mixed-phase clouds, however, only the Oruanui ash exhibited appreciable heterogeneous ice nucleation activity. Similar to recent studies on mineral dust, we suggest that the mineralogy of volcanic ash may dictate its ice nucleation activity in the immersion mode.
\end{abstract}

\section{Introduction}

It is estimated that approximately $9 \%$ of the world's population lives within $100 \mathrm{~km}$ of a historically active volcano (Small and Naumann, 2001) and at any moment at least 20 volcanoes around the globe may be erupting (Durant et al., 2010). In these areas, both gaseous and particulate volcanic emissions can affect both human respiratory health (Horwell and Baxter, 2006) and local environments (Witham et al., 2005). Further, explosive volcanic eruptions can greatly influence global climate, even for years after the initial eruption (Durant et al., 2010). For example, the eruption of Mt. Pinatubo in 1991 injected large amounts of gaseous sulfur species into the stratosphere, which perturbed the climate system for 2-3 years following the eruption (Robock, 2004).

In addition to gaseous emissions, explosive volcanoes generate large amounts of fine ash $(<63 \mu \mathrm{m})$, which is dispersed into the atmosphere via plumes above volcanic vents and pyroclastic flows. The global annual flux of fine volcanic ash into the atmosphere is approximately $200 \mathrm{Tg} \mathrm{yr}^{-1}$, based on a 1000 year average. While this flux is smaller than the terrestrial dust burden of approximately 1000 to $4000 \mathrm{Tg} \mathrm{yr}^{-1}$ (Huneeus et al., 2011), volcanic eruptions are often sporadic and can eject a large amount of particulate into the atmosphere over a short amount of time. Furthermore, water vapor is abundant in volcanic eruptions, with up to $8 \%$ of the pre-eruptive magma by mass (Durant et al., 2008). Thus, volcanic plumes represent prime conditions for cloud glaciation via heterogeneous ice nucleation, yet this phenomenon is vastly understudied considering its influence on plume dy- 
namics, volcanic lightning, sequestration of gaseous species, and the transport of these species to the stratosphere (Brown et al., 2012; McNutt and Williams, 2010; Kolb et al., 2010; Van Eaton et al., 2012). Further, fine ash from plumes can stay suspended in the upper troposphere for weeks to months and travel 1000s of kilometers; if these particles are efficient depositional ice nuclei, they could represent a widespread source of cold-cloud ice nuclei not currently parameterized in global models (Hoose et al., 2010).

Active volcanoes have long been known to influence ice nuclei (IN) concentrations in the atmosphere (Hobbs et al., 1971; Isono et al., 1959). For example, a study monitoring IN concentrations in Japan found concentrations were enhanced by a factor of 40 over background aerosol following the eruption of a nearby active volcano (Isono et al., 1959). In contrast, other studies have shown that IN concentrations near volcanic plumes were not elevated above typical background concentrations (Langer et al., 1974; Schnell and Delany, 1976). It was suggested, however, that the ash in some of these studies had been deactivated by chemical processing via gases in the volcanic cloud.

Laboratory studies probing the ice nucleation efficiency of volcanic ash have also shown it can act as heterogeneous IN (Durant et al., 2008; Hoyle et al., 2011). Unlike field measurements, however, it has been suggested that all volcanic ash may have similar ice nucleation efficacy, initiating ice formation in a relatively narrow temperature range of approximately 250 to $260 \mathrm{~K}$ (Durant et al., 2008); however, these works are difficult to interpret quantitatively, especially in cases where the nucleation mode is unclear, frozen fractions are unavailable, or the available surface area has not been quantified. More recently, several studies have investigated the deposition- and/or immersion-mode ice nucleation properties of ash from the 2010 eruption of the Eyjafjallajökull volcano in Iceland (Steinke et al., 2011; Hoyle et al., 2011; Bingemer et al., 2012). The results of these studies, combined with previous studies on large, $250-300 \mu \mathrm{m}$ ash particles from the $1980 \mathrm{Mt}$. St. Helens eruption (Fornea et al., 2009), suggest that there is one characteristic ice nucleation efficiency for all ash, even when accounting for frozen fractions and surface area (Murray et al., 2012). While such behavior would allow for a great simplification in models, these results represent only two volcanoes.. Thus, the question still remains of whether or not all volcanic ash exhibits similar ice nucleation activity regardless of the location, preeruptive magma composition, and mineralogy.

In this study, we have collected volcanic ash particles from the Fuego (Guatemala), Soufrière Hills (Montserrat), and Taupo (Oruanui eruption, New Zealand) volcanoes, which are basaltic $\left(45-52 \% \mathrm{SiO}_{2}\right)$, andesitic $\left(56-59 \% \mathrm{SiO}_{2}\right)$, and rhyolitic ashes (63-75\% $\mathrm{SiO}_{2}$ ) (Heiken, 1972), respectively. These samples were specifically chosen to represent three separate geographical locations, classifications by silica content, and percent minerals. For each of these ashes, we have probed their depositional ice nucleation and immersion freezing potential. The present experiment used to study depositional ice nucleation has been described previously; however, this paper represents our first measurements of immersion freezing. For the depositional nucleation experiments, the results are compared to previous results using the same system for the clay mineral kaolinite (KGa-1b, Sihvonen et al., 2014), which is generally thought to be an efficient depositional ice nucleus (Hoose and Möhler, 2012). For the immersion freezing experiments, the Raman microscope cold stage was validated using the same, standard kaolinite sample (Murray et al., 2011; Pinti et al., 2012). Using this validated system, we determined the ice nucleation active surface site densities of each volcanic ash sample by utilizing the singular description (Vali, 1994, 2008; Vali and Stansbury, 1966). The results and implications of these findings for cloud glaciation in volcanic plumes and the atmosphere are discussed.

\section{Experimental}

\subsection{Volcanic ash and standard minerals}

Volcanic ash was collected from three separate volcanic eruptions that produced three distinct types of ash. Volcán Fuego $\left(14.4828^{\circ} \mathrm{N}, 90.8828^{\circ} \mathrm{W}\right)$ is an active stratovolcano that lies $16 \mathrm{~km}$ north of Antigua, Guatemala. The sub-Plinian eruption of 14 October 1974 produced ash fall that impacted an area of $\sim 400 \mathrm{~km}^{2}$, and samples used here were collected by previous researchers immediately after eruption from a location $10 \mathrm{~km}$ from the vent. The Soufrière Hills volcano $\left(16.7167^{\circ} \mathrm{N}, 62.1833^{\circ} \mathrm{W}\right)$ is an active stratovolcano located in Montserrat, an island in the Lesser Antilles island arc of the West Indies. The ongoing eruption, which began in 1995, produces cyclic dome-building and explosive activity, with samples used here resulting from an explosion in January of 2010; samples were collected immediately after deposition $<3 \mathrm{~km}$ from the vent. Finally, the Taupo caldera $\left(38.8056^{\circ} \mathrm{S}, 175.9008^{\circ} \mathrm{E}\right)$ sits in the center of the North Island of New Zealand. Samples used here were collected from air fall deposits of the Oruanui ultra-Plinian eruption $\sim 26 \mathrm{ka}$. The samples were excavated $39 \mathrm{~km}$ from the vent $25.4 \mathrm{ka}$ after the eruption.

Volcanic ash (pyroclasts $<2 \mathrm{~mm}$ ) dominantly consists of silica-rich volcanic glass and crystalline minerals. The chemical composition of volcanic ash is mainly determined from its parent magma, although lithic material from the vent may play a role in modifying the composition of the aerosolized ash. Since the main chemical elements of magma are Si and $\mathrm{O}$, magma is often classified by its silica content, which increases in the following order: basaltic $\left(45-52 \% \mathrm{SiO}_{2}\right)$, andesitic (56-59\% $\left.\mathrm{SiO}_{2}\right)$, and rhyolitic $\left(63-75 \% \mathrm{SiO}_{2}\right)$ (Heiken, 1972). It is important to note that silica content of the ash is determined from elemental analyses, most commonly as X-ray fluorescence, and will include Si contribu- 
tions from the melt glass, minerals, and lithic materials in the ash; this is not to be confused with quartz, which can be one mineral component of the ash composed of pure, crystalline $\mathrm{SiO}_{2}$. Each parent magma has a different melting temperature, viscosity, and volatile content (dominantly $\mathrm{H}_{2} \mathrm{O}$ ); further, the assemblage and composition of minerals often reflect their host melt (Langmann, 2014). The silica content and $\%$ crystals, taken from previous whole-rock studies, for each of the volcanoes are shown in Table 1. As shown, the Fuego, Soufrière Hills, and Oruanui whole-rock samples represent a range of magma compositions and contain varying amounts of crystalline material. Chemical differences due to collection distances from the vent or environmental aging were not explicitly taken into account in this study. From these bulk studies, the primary mineral for all three samples was found to be plagioclase, a tetrosilicate material in the feldspar family; however the samples vary in their next abundant mineral. For the Fuego, Soufrière Hills, and Oruanui samples, the second-most abundant mineral is olivine, amphibole, and quartz, respectively.

A low-defect kaolinite from Washington County, GA, USA (KGa-1b) was obtained from the Source Clays Repository of the Clay Mineral Society (West Lafayette, IN, USA). KGa-1b was chosen because it has previously been studied in ice nucleation literature in both the deposition and immersion mode (Hoose and Möhler, 2012; Murray et al., 2012). Soda feldspar [Standard Reference Material (SRM) 99b], a standard $\mathrm{Na} / \mathrm{Ca}$ feldspar, was obtained from the National Institute of Standards and Technology (NIST) as a homogenous, fine powder $(<60 \mu \mathrm{m})$.

\subsection{Raman microscope and environmental cell}

The Raman microscope has been described previously in detail (Baustian et al., 2010; Schill and Tolbert, 2013). Briefly, a Nicolet Almega XR Raman spectrometer has been coupled to a research grade Olympus BX-51 microscope with 10x, 20x, 50x, and 100x magnification objectives. This Raman microscope has been outfitted with a Linkam THMS600 environmental cell. The temperature of a cold stage inside the cell is controlled by a Linkam TMS94 automated temperature controller with an accuracy of $0.1 \mathrm{~K}$. Water partial pressure inside the cell is controlled by mixing dry and humidified flows of $\mathrm{N}_{2}$ and measured using a Buck Research CR-A1 dew point hygrometer in line with the cell. The accuracy of the dew point hygrometer is $0.15 \mathrm{~K}$. The relative humidity $(\mathrm{RH})$ and ice saturation ratio $\left(S_{\text {ice }} d=P_{\mathrm{H}_{2} \mathrm{O}} / \mathrm{VP}_{\text {ice }}\right)$ inside the cell are determined by ratioing the partial pressure of water to the equilibrium vapor pressure of water and ice, respectively (Murphy and Koop, 2005). A Gast diaphragm pump at the exit of the hygrometer ensures that the gas flow through the cell and hygrometer is $1 \mathrm{~L} \mathrm{~min}^{-1}$.

Stokes-mode Raman spectra were obtained using a $532 \mathrm{~nm}$ frequency-doubled Nd:YAG, as the excitation laser. Spectra were taken from 200 to $4000 \mathrm{~cm}^{-1}$ with a typical resolution of $2-4 \mathrm{~cm}^{-1}$. Spectra were taken at the center of each particle and typically consisted of 256 co-added scans and were taken with 50x and 100x long-range objectives, which focus the laser to a spot size of approximately 1.3 and $1.1 \mu \mathrm{m}$, respectively (Everall, 2010).

\subsection{Depositional freezing}

For depositional freezing experiments, approximately $100 \mathrm{mg}$ of ash was ground in a porcelain mortar and pestle. To the ground ash, $8.0 \mathrm{~mL}$ of ultra-pure water was added and the slurry was immediately aspirated into a Meinhard TR-50 glass concentric nebulizer. Nebulized droplets were directed at a fused-silica disc and allowed to coagulate into supermicron droplets. The sample disc was then transferred into the environmental cell and exposed to a low-humidity environment. This caused water evaporation, resulting in aggregated ash particles ranging from 1 to $20 \mu \mathrm{m}$ in lateral diameter. Similar composite or aggregate volcanic ash samples are often found in the atmosphere, and are produced by a similar mechanism (Brown et al., 2012). To assure that minimal chemical alteration occurred from grinding and nebulizing the ash samples, Raman spectra of unground, ground, and ground/nebulized and dried ash were obtained. An example set of these spectra for Soufrière Hills ash is shown in Fig. 1. It can be seen that the main ash signatures at 507,408 , and $281 \mathrm{~cm}^{-1}$ in the Raman spectra are not significantly altered between the unground, ground, and aggregated particles, indicating that any major chemical alteration due to ash processing was not detected for these samples. A small peak at $663 \mathrm{~cm}^{-1}$, however, does appear in the ground and ground/nebulized and dried ash; we attribute this peak to better homogeneity of minor components within the ground samples as compared to the unground samples.

Depositional nucleation experiments were conducted from 225 to $235 \mathrm{~K}$. Experiments consisted of increasing ice supersaturation over the sample by holding a constant vapor pressure of water and lowering the temperature until the first ice event was noted. Specifically, after the particles were allowed to sit at $298 \mathrm{~K}$ and $\sim 0 \% \mathrm{RH}$ for at least $10 \mathrm{~min}$, the temperature was decreased at a rate of $10 \mathrm{~K} \mathrm{~min}^{-1}$, until $S_{\text {ice }} \sim 0.9$. The temperature was then decreased at a rate of $0.1 \mathrm{~K} \mathrm{~min}^{-1}$, which corresponds to an $S_{\text {ice }}$ ramp rate of $0.01 \mathrm{~min}^{-1}$, until the first ice event was noted. Initial observation of ice was monitored by scanning the entire disc using the 10x objective. After the first ice particle was detected, the 50x objective was utilized to verify the existence of ice both visually (Fig. 2a) and spectrally. Finally, the ice was sublimed by turning off the flow of the humidified nitrogen to ensure that ice had formed on an ash particle instead of the fused-silica disc (Fig. 2b). We have previously reported the conditions under which a blank fused-silica disc initiates ice formation (Baustian et al., 2010). In that study, we found that the blank substrate nucleated ice at $S_{\text {ice }}$ of 1.6 to 2.33 from $\sim 235$ to $215 \mathrm{~K}$. 
Table 1. Silica content, \% crystals from previous whole-rock studies, XRD \% crystallinity and \% amorphous, and the BET surface areas of representative volcanic rock and ash samples from the Fuego, Soufrière Hills, and Taupo volcanoes and powdered NIST SRM-99b Na / Ca feldspar.

\begin{tabular}{lccccc}
\hline Sample & $\begin{array}{c}\text { Silica content } \\
(\mathrm{wt} \%)\end{array}$ & $\begin{array}{c}\% \\
\text { crystals }\end{array}$ & $\begin{array}{c}\text { XRD } \\
\% \text { crystallinity }\end{array}$ & $\begin{array}{c}\text { XRD } \\
\% \text { amorphous }\end{array}$ & $\begin{array}{c}\text { BET surface area } \\
\left(\mathrm{m}^{2} \mathrm{~g}^{-1}\right)\end{array}$ \\
\hline Fuego (Guatemala) & $50.6^{\mathrm{a}}$ & $38 \mathrm{vol} \%{ }^{\mathrm{a}}$ & $63 \pm 3$ & 37 & $5.14 \pm 0.03$ \\
Soufrière Hills (Monserrat) & $59.13^{\mathrm{b}}$ & $60-87 \mathrm{wt} \% \mathrm{~b}$ & $89 \pm 3$ & 11 & $6.30 \pm 0.04$ \\
Taupo (Oruanui, New Zealand) & $74.15^{\mathrm{c}}$ & $3-13 \mathrm{wt} \%^{\mathrm{c}}$ & $41 \pm 3$ & 59 & $9.23 \pm 0.04$ \\
$\mathrm{Na} / \mathrm{Ca}$ feldspar (NIST) & - & - & $100 \pm 3$ & 0 & $1.219 \pm 0.008$ \\
\hline
\end{tabular}

${ }^{a}$ Rose et al. (1978) ${ }^{b}$ Murphy et al. (2000) ${ }^{c}$ Wilson et al. (2006)

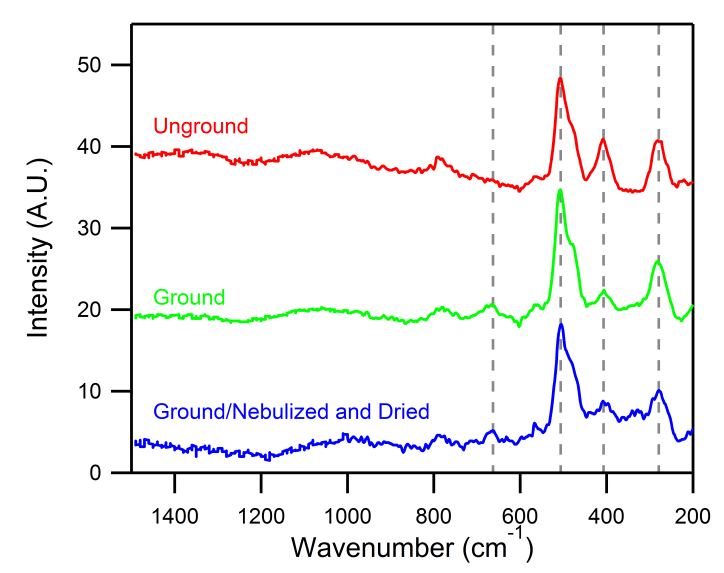

Figure 1. A set of example Raman spectra of unground, ground, and ground/nebulized Soufrière Hills volcanic ash. As shown, the main peaks at 507, 408, and $281 \mathrm{~cm}^{-1}$ (vertical dashed lines) are minimally affected by mechanical grinding and wet generation, suggesting that bulk chemical alteration does not occur. A small peak at $663 \mathrm{~cm}^{-1}$, however, does appear in the ground samples, possibly due to better homogeneity of minor components compared to unground samples.

\subsection{Immersion freezing experiments}

For immersion freezing experiments, it was important to ensure that the concentration of volcanic ash or standard mineral in each drop was the same. Grinding with a mortar and pestle produced samples too coarse to meet these requirements. Thus, for immersion freezing experiments, a Wig-LBug $^{\circledR}$ amalgamator (Crescent/Rinn Dental Mfg.) was used to pulverize volcanic ash or standard minerals (Hudson et al., 2008; Curtis et al., 2008). Specifically, approximately $100 \mathrm{mg}$ of material was placed in a hardened stainless steel vial containing a stainless steel ball pestle. The samples were pulverized in four 5-min intervals, for a total of 20 minutes. The samples were allowed to rest for $5 \mathrm{~min}$ between intervals to avoid overheating of the sample. After treatment with the Wig-L-Bug $^{\circledR}$, the samples were made into $0.5,1.0$, and/or $2.0 \mathrm{wt} \%$ solutions with ultra-pure water. The concentration of material in suspensions was determined gravimetrically.

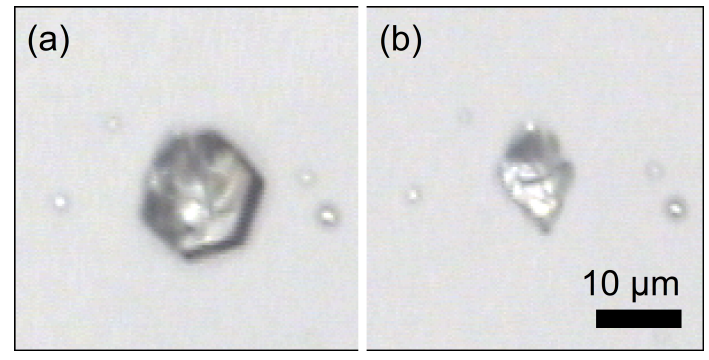

Figure 2. 50x optical image of an ice particle at $225 \mathrm{~K}$ (a) and its Fuego ash nucleus (b).

Sample solutions were shaken for at least $12 \mathrm{~h}$ prior to ice nucleation experiments; this prevented unnecessary aggregation, and, therefore, ensured better homogeneity between droplets. To generate droplets for an immersion freezing experiment, a known weight-percent solution was aspirated into a Meinhard TR-30 glass concentric nebulizer. To mitigate gravimetric settling prior to nebulization, humidified nitrogen was vigorously bubbled through the sample solutions immediately before aspiration. Humidified $\mathrm{N}_{2}$ was used as the carrier gas to prevent excess evaporation at the nebulizer nozzle (Todoli and Mermet, 2011). The nebulized spray was directed at a hydrophobically treated fused-silica disc, and the nebulized droplets were allowed to coagulate into supermicron droplets. After nebulization, the disc was immediately capped with an indium spacer (Alfa Aesar, $127 \mu \mathrm{m}$ thick) and a second fused-silica disc. The spacer was coated with Apiezon L high-vacuum grease to ensure good contact to the discs, which helped maintain a saturated humidity in the space created by the indium spacer (immersion cell). By taking the above precautions, the concentration of ash in each particle is assumed to be the same as the concentration of ash in the nebulized solution. To confirm this, droplets were examined under 50x magnification prior to each experiment to ensure that their ash concentrations were visually similar. Despite low relative humidities inside the environmental cell, droplets inside the immersion cell did not visibly grow or shrink, even after sitting for $12 \mathrm{~h}$. 

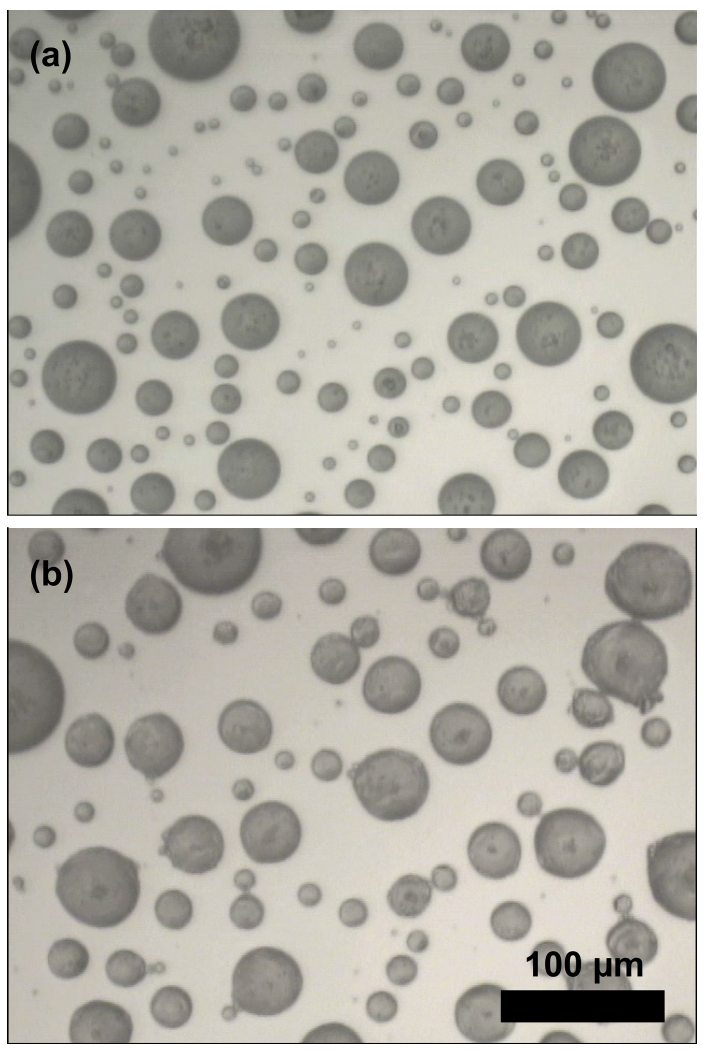

Figure 3. 20x images of unfrozen droplets containing $1 \% \mathrm{KGa}-1 \mathrm{~b}$ (a), and the same drops after an immersion freezing experiment (b).

Freezing experiments were video recorded under $10 \mathrm{x}$ or 20x magnification at 30 frames per second, and freezing events were identified by the sudden appearance of structure within droplets. Droplets were cooled from approximately 5 to $-40{ }^{\circ} \mathrm{C}$ at a rate of $10 \mathrm{~K} \mathrm{~min}^{-1}$. An example of droplets at the beginning of an immersion freezing experiment prior to freezing and the same droplets after all had frozen can be seen in Fig. 3a and b, respectively. Ice nucleation frozen fractions were calculated as a function of temperature. Frozen fraction curves were separated into two different size bins: 10-60 and 65-165 $\mu \mathrm{m}$ (droplet size, lateral diameter). These size bins span droplet volumes from $\sim 1.3 \mathrm{pL}$ to $0.7 \mathrm{~nL}$. In some cases, larger ice particles would grow at the expense of smaller droplets in the cell. If these smaller droplets completely evaporated by the end of the experiment, they were disregarded in our analysis. Further, by recording 30 frame-per-second video, we could unambiguously determine if droplets coagulated or froze by contact freezing. In all experiments, no contact-freezing events occurred from the contact of two liquid drops. If two droplets coagulated, only their coagulated droplet size was considered. Unfrozen droplets, however, could be frozen by contact with growing ice particles; those contact-frozen droplets were disregarded in our analysis. To minimize liquid droplet shrinking and contact freezing by growing ice crystals, we chose a cooling rate of $10 \mathrm{~K} \mathrm{~min}^{-1}$. This rate strikes a balance of minimizing the aforementioned mass-transfer effects while avoiding a measurable temperature offset between the measured and actual temperature of the particles on the fused-silica disc due to heat-transfer limitations that occur at higher cooling rates (Koop et al., 1998). Errors in $n_{\mathrm{S}}$ values are based on the range of surface areas available in each experiment. The temperature error of $0.5 \mathrm{~K}$ for all droplets was determined by repeated homogeneous freezing experiments of ultra-pure water.

\subsection{Brunaur-Emmet-Teller surface areas}

Brunaur-Emmet-Teller (BET) surface area analysis was conducted by Pacific Surface Sciences Inc. using a Micrometric TriStarr II surface area analyzer. For BET analysis, ash samples and $\mathrm{Na} / \mathrm{Ca}$ feldspar were prepared exactly as for immersion freezing experiments, but were not suspended in high-purity water. The samples were degassed under flowing ultra-high purity grade nitrogen for $2 \mathrm{~h}$ at a temperature of $200^{\circ} \mathrm{C}$ and the surface area was measured. Nitrogen gas adsorption measurements were taken at relative pressures of $0.05,0.1,0.15,0.2$, and 0.25 . The free space in the analysis tube was measured by the Helium method. The five pressure points were used to calculate the BET surface area. In this study, we determined the BET surface areas for all three volcanic ash samples and $\mathrm{Na} / \mathrm{Ca}$ feldspar (Table 1).

\subsection{X-Ray diffraction analysis}

X-Ray diffraction (XRD) analysis of volcanic ash and $\mathrm{Na} / \mathrm{Ca}$ feldspar was conducted by X-Ray Wizards, LLC. Similar to BET analysis, each sample was prepared exactly as for immersion freezing, but was not suspended into solution. Data were collected with a Bruker D8 Discover instrument with a scintillation detector, $\mathrm{Cu}$ radiation, and appropriate slits for high resolution. Percent crystallinity and associated $\%$ amorphous were determined by profile-fitting and degree of crystallinity measurements using the Bruker Rietveld refinement (Table 1). Phase identification and quantitative analysis were used to determine the identity and relative amount of each phase in a mixture, and each identified mineral is reported as a wt \% (Table 2). The quantitative analysis was done via reference intensity ratio.

\section{Results and discussion}

\subsection{Depositional ice nucleation on volcanic ash samples}

Depositional ice nucleation experiments using the Raman microscope have previously been validated (Baustian et al., 2010; Wise et al., 2010). The critical $S_{\text {ice }}$ needed for the onset of depositional ice nucleation on all three ash samples from 225 to $235 \mathrm{~K}$ is shown in Fig. 4. It can be seen that all three ash samples exhibit minimal temperature dependence 
Table 2. The mineralogical composition of Fuego, Soufrière Hills, and Oruanui volcanic ash and NIST SRM-99b Na / Ca feldspar as determined by XRD.

\begin{tabular}{|c|c|c|c|c|c|c|c|}
\hline Mineral/Sample & $\begin{array}{l}\text { Anorthite } \\
\mathrm{Ca} / \mathrm{Na}- \\
\text { feldspar }\end{array}$ & $\begin{array}{l}\text { Albite } \\
\mathrm{Na} / \mathrm{Ca}- \\
\text { feldspar }\end{array}$ & $\begin{array}{r}\text { Microcline } \\
\text { K- } \\
\text { feldspar }\end{array}$ & $\begin{array}{r}\text { Quartz } \\
\mathrm{SiO}_{2}\end{array}$ & $\begin{array}{r}\text { Enstatite } \\
\text { ortho- } \\
\text { pyroxene }\end{array}$ & $\begin{array}{l}\text { Riebeckite } \\
\text { magnesio- } \\
\text { hornsblende }\end{array}$ & $\begin{array}{l}\text { Other } \\
\text { (trace) }\end{array}$ \\
\hline Fuego & 36 & 64 & - & - & - & - & - \\
\hline Soufrière Hills & 10 & 71 & - & 1 & 11 & 7 & - \\
\hline Oruanui & 26 & 47 & - & 27 & - & - & - \\
\hline $\mathrm{Na} / \mathrm{Ca}$ feldspar (NIST) & - & 69 & 18 & 13 & - & - & $\begin{array}{l}\text { Anorthite, } \\
\text { Anorthoclase, } \\
\text { Barium silicate } \\
\text { Hydrate }\end{array}$ \\
\hline
\end{tabular}

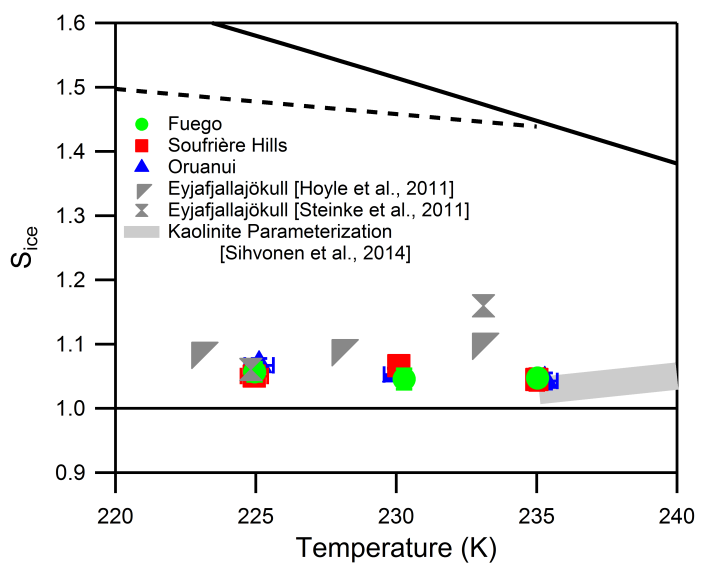

Figure 4. The onset $S_{\text {ice }}$ as a function of temperature for ice nucleation on volcanic ash samples. The thick and thin solid lines refer to water and ice saturation respectively. The dashed line represents the $S_{\text {ice }}$ values for homogeneous nucleation of an aqueous droplet (Koop et al., 2000). Also included are onset results from depositional ice nucleation experiments on ash from the 2010 Eyjafjallajökull eruption (Hoyle et al., 2011; Steinke et al., 2011) and a parameterization for depositional ice nucleation on KGa-1b (Sihvonen et al., 2014).

and similar ice nucleation activity to each other at the temperatures explored. Further, all three ash samples require low ice supersaturations $\left(S_{\text {ice }}=1.05 \pm 0.01\right)$ to nucleate ice and, therefore, are efficient ice nuclei in the temperature range investigated. Also shown in Fig. 4 are onset results from depositional ice nucleation experiments on ash from the 2010 Eyjafjallajökull eruption from Hoyle et al. (2011) and Steinke et al. (2011). Here, even the Icelandic ash has similar ice nucleation activity to the three types of ash used in this study. To further highlight their depositional ice nucleation efficiency, a parameterization of the critical ice saturation ratio of kaolinite from a previous study (Sihvonen et al., 2014) has also been added to Fig. 4. Since these results were taken with the same instrument for similar frozen fractions and surface areas, these results are directly comparable. Thus, these results suggest it is possible that all volcanic ash studied to date are as efficient as clay minerals for ice nucleation in the depositional mode.

To attempt to elucidate why these ash samples had similar, efficient depositional ice nucleation abilities, we compared the $\%$ crystallinity and mineralogy for each ash. In Table 1 , it can be seen that the $\%$ crystallinity from our XRD results and the \% crystals from literature can be different. This indicates that finer ash-sized fractions may have different properties from representative whole-rock samples; thus, in this study we will only consider the \% crystallinity and mineralogy that we directly determined by XRD analysis. By comparing Fig. 4 with Table 1, it can be seen that the $\%$ crystallinity and $\%$ amorphous material between ash samples are different, but the $S_{\text {ice }}$ onsets are similar. Therefore, the total amount of crystalline vs. amorphous material is likely not the sole factor in determining depositional ice nucleation. Table 2 indicates the detectable crystalline material and their abundances $( \pm 3 \%)$. As shown, each of the ash samples contains a considerable amount of plagioclase, either albite, a sodium-rich $\mathrm{Na} / \mathrm{Ca}$ feldspar, or anorthite, a calcium-rich $\mathrm{Na} / \mathrm{Ca}$ feldspar. Feldspar minerals, both $\mathrm{K}$ feldspar and $\mathrm{Na} / \mathrm{Ca}$ feldspar, have previously been shown to be among the most efficient depositional ice nuclei, comparable to kaolinite, Arizona test dust, and Mojave Desert dust (Yakobi-Hancock et al., 2013). Thus, we suggest that $\mathrm{Na} / \mathrm{Ca}$ feldspar could be dictating the ice nucleation behavior of volcanic ash. It is important to note that the above discussion only interprets ice nucleation efficiency in terms of a chemical mechanism. The alteration of physical active sites from mechanical grinding or wet generation could increase depositional ice nucleation efficiency; however, our results were comparable to both studies on the Eyjafjallajökull ash, which used dry sieving to size select samples and aerosolized using dry-generation techniques (Steinke et al., 2011; Hoyle et al., 2011). 


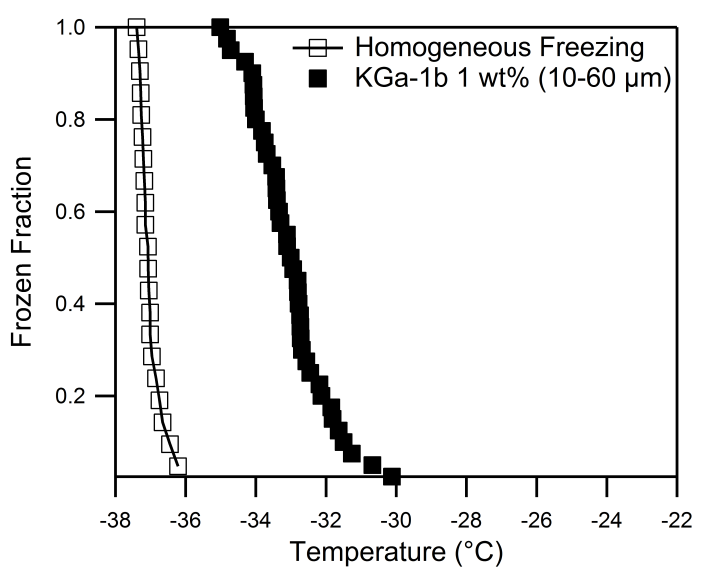

Figure 5. Frozen fraction curve for $1 \mathrm{wt} \% \mathrm{KGa}-1 \mathrm{~b}$ in $10-60 \mu \mathrm{m}$ droplets as a function of temperature. Also shown are results for freezing of ultra-pure water droplets (homogeneous freezing).

\subsection{Validation of immersion freezing experiments with kaolinite}

To validate our immersion freezing experiments, we ran test experiments on KGa-1b. KGa-1b was chosen because its ice nucleation behavior has been well studied in the immersion freezing mode using both cold stage and continuous flow instruments (Murray et al., 2011; Pinti et al., 2012). Our results for freezing of 10-60 $\mu \mathrm{m}$ droplets containing $1 \mathrm{wt} \% \mathrm{KGa}-1 \mathrm{~b}$ are shown in Fig. 5. In this experiment, the cumulative fraction of frozen droplets $[\mathrm{FF}(T)]$ was determined as a function of temperature:

$\mathrm{FF}(T)=\frac{n_{\text {ice }}(T)}{n}$,

where $n_{\text {ice }}(T)$ is the total number of frozen droplets at temperature $T$ and $n$ is the total number of frozen droplets at $-39.55^{\circ} \mathrm{C}$. Also shown are results for homogeneous freezing of 10-60 $\mu \mathrm{m}$ ultra-pure water droplets from our experimental setup. As expected, the homogeneous freezing curve rises steeply at $\sim-37^{\circ} \mathrm{C}$. The droplets containing $1 \%$ kaolinite freeze at higher temperatures than the homogeneous freezing curve; thus, the droplets must be freezing heterogeneously. Differences in droplet size bins, ash concentration, and droplet contact angle with the substrate affect both the surface area available for ice nucleation and the subsequent frozen fraction at each temperature. This renders it difficult to directly compare these results to former freezing spectra using different experimental setups. It has, however, been shown in the past that inter-instrumental comparisons of mineral dust can be made by invoking the singular approximation (Vali, 1994, 2008; Broadley et al., 2012; Niemand et al., 2012). Here, the time dependence of freezing events is considered to be of secondary importance to the temperature dependence. In this vein, a simplified quantification of the observed frozen fractions and temperature onsets can be made by the metric of ice nucleation active site (INAS) densities $\left(n_{\mathrm{S}}\right)$ (DeMott et al., 1994), which is defined as

$n_{\mathrm{S}}\left(T, S_{\text {ice }}\right)=-\frac{\ln \left[1-\mathrm{FF}\left(T, S_{\text {ice }}\right)\right]}{\mathrm{SA}_{\text {aerosol }}}$,

where $\mathrm{SA}_{\text {aerosol }}$ is the average surface area per particle. Our $n_{\mathrm{s}}$ values for $\mathrm{KGa}-1 \mathrm{~b}$ as a function of temperature, calculated under the singular description, can be found in Fig. 6a. For $\mathrm{SA}_{\text {aerosol }}$, the BET specific surface area was used. The BET surface area for KGa-1b was assumed to be $11.8 \mathrm{~m}^{2} \mathrm{~g}^{-1}$ (Murray et al., 2011). Also shown in Fig. 6a is an $n_{\mathrm{s}}$ parameterization for KGa-1b from Murray et al. (2011), who used a cold stage to determine the immersion freezing potential of KGa- $1 \mathrm{~b}$ for 0.2 to $1 \mathrm{wt} \%$ solutions using various cooling rates. Our results lie slightly under the Murray parameterization; however, in our analysis we have ignored the time dependence of freezing events. While this may be valid for complex samples with a distribution of ice active sites (Niemand et al., 2012), it has been shown that one must take the time dependence for a pure clay mineral like kaolinite into account (Murray et al., 2011). Despite this, our data analyzed under the singular approximation are only 1 order of magnitude off from the parameterization. To take into account the time dependence, we invoke the modified singular theory (Vali, 2008). Here, the $n_{\mathrm{s}}$ value is modified to represent a single cooling rate. The parameterization is as follows:

$n_{\mathrm{s}}\left(T, S_{\text {ice }}\right)=-\frac{\ln \left[1-\mathrm{FF}\left(T-\alpha, S_{\text {ice }}\right)\right]}{\mathrm{SA}_{\text {aerosol }}}$,

where the variable $\alpha$ is an offset in temperature from a freezing spectrum recorded at a cooling rate of $1 \mathrm{~K} \mathrm{~min}^{-1}$. This is related to the cooling rate $(r)$ by the equation

$\alpha=\beta \log (|r|)$,

where $\beta$ is an empirical parameter. Our same $\mathrm{KGa}-1 \mathrm{~b}$ data parameterized using the modified singular description with $\beta=2.01$ (Murray et al., 2011) can be found in Fig. 6b. Now our data are in excellent agreement with the Murray parameterization. Thus, for immersion freezing, we find that the Raman microscope cold stage setup can be used to intercompare inherent immersion freezing abilities of particle types to other instruments under the singular or modified singular approximation. This ability of the Raman microscope cold stage to determine the inherent immersion freezing ability of NX-Illite nanopowder has also been verified (Hiranuma et al., 2015).

\subsection{Immersion freezing of droplets containing volcanic ash samples}

The immersion freezing results from 0.5, 1.0, and $2.0 \mathrm{wt} \%$ Oruanui, Soufrière Hills, and Fuego volcanic ash are shown in Fig. 7. The Oruanui ash samples serve as heterogeneous immersion-mode ice nuclei for all wt \% explored (Fig. 7a). In 

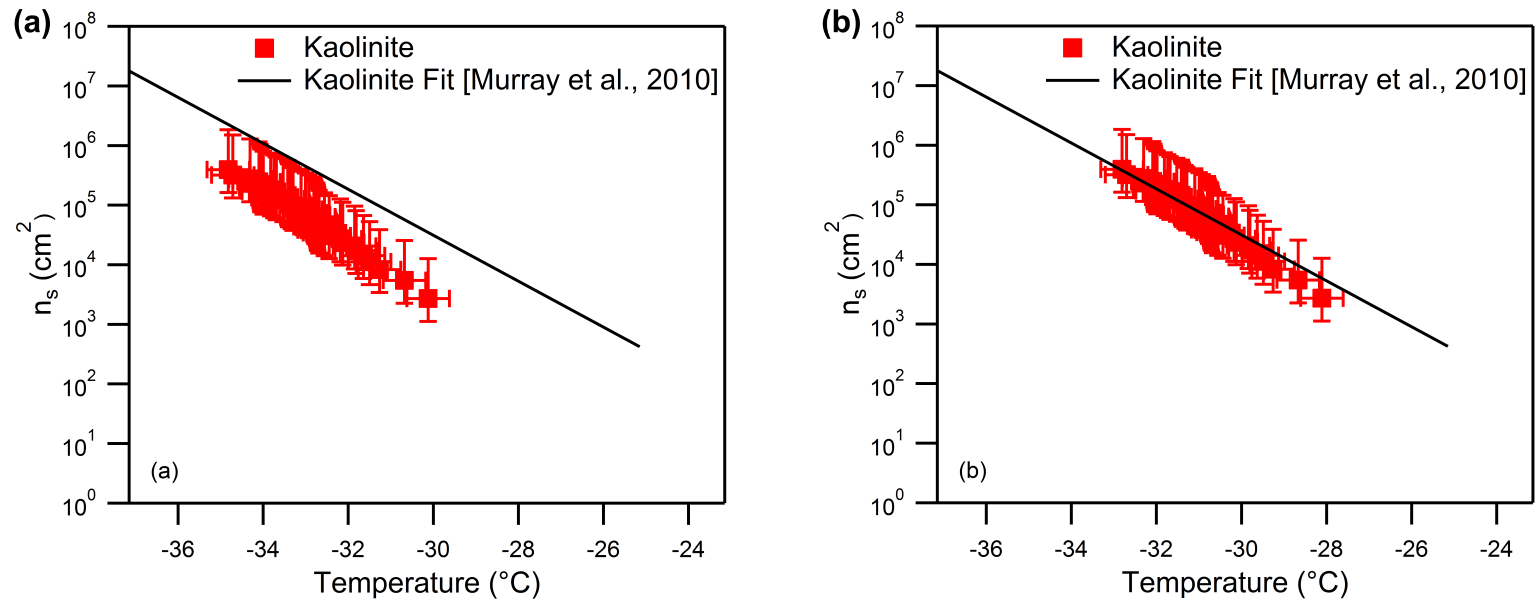

Figure 6. Ice nucleation active surface site densities for KGa-1b as a function of temperature using the singular description (a) and the modified singular description (b).

general, increasing the wt $\%$ of ash in each droplet increases the freezing temperature. This is expected as increasing the wt $\%$ of ash in each droplet increases the total surface area available for heterogeneous ice nucleation for a similar-sized droplet population. Although their freezing spectra have different shapes, the temperature at which $50 \%$ of $1 \%$ Oruanui ash droplets were frozen $\left(\mathrm{FF}_{0.5}\right)$ coincides with the $\mathrm{FF}_{0.5}$ of $1 \% \mathrm{KGa}-1 \mathrm{~b}$, indicating that they may have similar immersion freezing abilities. Unlike the depositional freezing results, the immersion freezing activity of the Soufrière Hills ash is not similar to the Oruanui ash (Fig. 7b). In fact, the FF curve for 10-60 $\mu \mathrm{m}$ droplets containing $2 \mathrm{wt} \%$ Soufrière Hills ash overlaps with the ultra-pure water curve, implying that these droplets froze homogeneously. Increasing the droplet size range to $65-165 \mu \mathrm{m}$ only produces a few special IN at $T>-37^{\circ} \mathrm{C}$; however, most droplet freezing events still coincide with the homogeneous freezing curve. For 65 $165 \mu \mathrm{m}$ droplets containing $2 \mathrm{wt} \%$ Soufrière Hills ash, the total available surface areas correlate to ash particles with spherical equivalent diameters of 23.0-53.6 $\mu \mathrm{m}$, which forms a large subset of fine volcanic ash. The Fuego ash has similar immersion freezing behavior to the Soufrière Hills ash, despite coming from a different region and having different silica content (Fig. 7c). Again, for $10-60 \mu \mathrm{m}$ droplets containing $2 \mathrm{wt} \%$ Fuego ash, the FF curve coincides with the homogeneous freezing FF spectrum. Further, for 65-165 $\mu \mathrm{m}$ droplets containing $2 \mathrm{wt} \%$ Fuego ash, whose total available surface area corresponded to ash particles 23.4 and $58.0 \mu \mathrm{m}$ in spherical diameter, only a few special IN at $T>-37{ }^{\circ} \mathrm{C}$ are found.

Since these ash samples contain different wt $\%$ ash, droplet size populations, and ashes with different surface areas, it is difficult to directly compare inherent ice nucleation activity from the freezing spectra. Thus, we have calculated the $n_{\mathrm{s}}$ values for these ash samples under the singular approximation (Fig. 8). For each ash, the BET specific surface area was used as determined in this study (Table 1). The modified singular approximation was not used because larger particle-to-particle variability of ice active sites is expected for these complex samples, limiting the importance of time dependence (Broadley et al., 2012; Hiranuma et al., 2015). As shown in Fig. 8, the Oruanui ash is inherently a better ice nucleus than either the Soufrière Hills or Fuego Ash, which are similar to each other. Also shown in Fig. 8 are $n_{\mathrm{s}}$ values of Mt. St. Helens and Eyjafjallajökull ash from previous studies (Hoyle et al., 2011; Steinke et al., 2011; Murray et al., 2012). The Oruanui ash sits below these points; however it should be noted that the surface area of the Eyjafjallajökull and Mt. St. Helens ash were estimated using their geometrical surface area. Due to the high degree of aggregation and porosity of volcanic ash particles, the geometrical surface area could be vastly underestimating the true surface area. To estimate this effect, we have re-plotted the volcanic ash parameterization found in Murray et al. (2012), assuming that the true surface area is 10 times greater than the estimated geometrical surface area. This is not an unreasonable assumption, since the geometrical surface area would underestimate the true surface area 4-20 times for ash particles $1-5 \mu \mathrm{m}$ in diameter, assuming a BET surface area for Oruanui ash and a density of $2.6 \mathrm{~g} \mathrm{~m}^{-3}$. The adjusted parameterization is shown in Fig. 8 as a dashed line. As shown, estimating the surface area as 10 times greater than the geometrical surface area brings the parameterization much closer to our results. Thus, although the Oruanui ash has different surface-area normalized ice nucleation abilities than the Fuego and Soufrière Hills ash used in this study, it appears to be similar to the Eyjafjallajökull and Mt. St. Helens ash. 

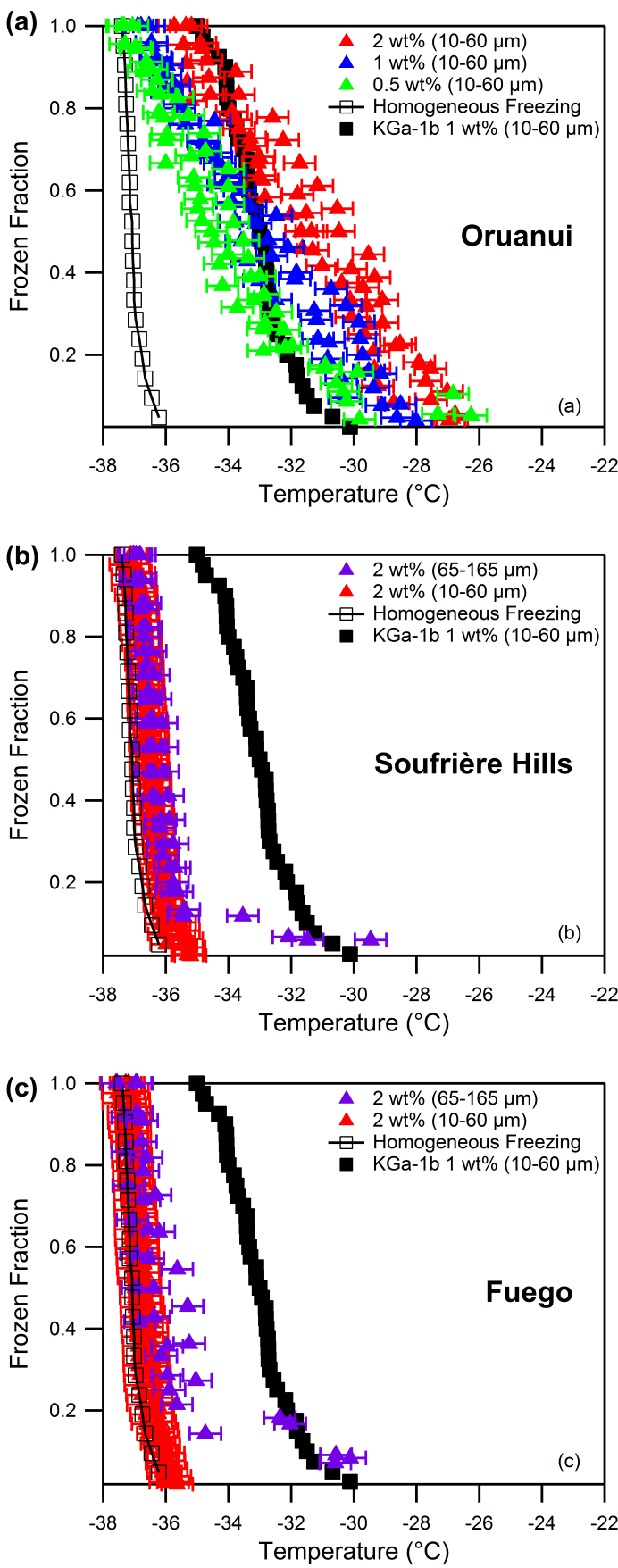

Figure 7. Frozen fraction curves as a function of temperature for $0.5,1.0$, and/or 2 wt \% Oruanui ash (a), Soufrière Hills (b), and Fuego Ash (c).

\subsection{Immersion freezing of droplets containing $\mathrm{Na} / \mathrm{Ca}$ feldspar}

Recently, it has been shown that $\mathrm{K}$ feldspar is an extremely efficient ice nucleus and, consequently, may dictate the ice nucleation ability of natural mineral dust, even though it is only found in low weight percentages (Atkinson et al.,
2013). That study also determined the ice nucleation ability of $\mathrm{Na} / \mathrm{Ca}$ feldspar from the Bureau of Analysed Samples (United Kingdom), and found that it was also an efficient immersion ice nucleus. In our results, we found that neither the Fuego nor Soufrière Hills ash acted as efficient immersion freezing ice nuclei for the concentrations and droplet sizes that we explored. While the Fuego and Soufrière Hills ash both contained significant feldspar, it was almost exclusively the $\mathrm{Na} / \mathrm{Ca}$ feldspar. To explore this further, we conducted immersion freezing experiments on NIST SRM 99b, a Na / Ca feldspar standard. We also conducted XRD on these samples, and found that they contained $\mathrm{K}$ feldspar and quartz impurities in addition to $\mathrm{Na} / \mathrm{Ca}$ feldspar (Table 2). The frozen fraction curves for NIST SRM $99 \mathrm{~b}$ are plotted in Fig. 9 and their $n_{\mathrm{s}}$ values are shown in Fig. 8. As shown, the NIST SRM 99b is also an efficient ice nucleus. We suggest that the high immersion freezing activity of the NIST $99 \mathrm{~b}$ soda feldspar is due to the $\mathrm{K}$ feldspar impurities, in agreement with previous studies (Atkinson et al., 2013). These combined results suggest that $\mathrm{Na} / \mathrm{Ca}$ feldspar may be inactive in the immersion mode despite being very active for depositional nucleation. This is in agreement with Zolles et al. (2015), who found that the $\mathrm{Na} / \mathrm{Ca}$ feldspars albite, anorthian andesine, and an albite-dominated ash sample were all weak immersion-mode IN. Thus, from examining Table 2, we suggest that the immersion freezing activity of the Oruanui ash is likely due to the quartz. This is in agreement with previous findings, which found that quartz was the secondmost efficient immersion-mode nuclei mineral found in mineral dust behind feldspars (Atkinson et al., 2013).

It is important to note that the above discussion interprets immersion freezing only from a chemical mechanism standpoint. The ash samples used here were collected at various distances from the volcano and represent various magnitudes of eruption explosivity, which affects grain morphology and the grain size distribution of the fall deposit, however, it is important to note that these samples were processed prior to immersion freezing. Namely, even after size sorting, the particles were pulverized from larger ash particles and immersed in water and shaken for at least $12 \mathrm{~h}$ prior to immersion freezing experiments. Pulverizing the ash particles has two possible effects on ice nucleation. First, it could introduce new, physical active sites. For example it has been shown for hematite particles that mechanical milling can change the ice nucleation surface site density, even when accounting for changes in surface area (Hiranuma et al., 2014). Second, it could liberate and/or expose mineral surfaces that were previously encased in volcanic glass. Both of these effects, however, are expected to increase ice nucleation activity and do not account for the inactivity of the Fuego and Soufrière Hills ashes in the immersion mode. Further, in some cases, approximately $70 \%$ of fine ash particles $(<63 \mu \mathrm{m})$ are largely aggregates of smaller particles (Brown et al., 2012). Thus, pulverizing with the Wig-L-Bug ${ }^{\circledR}$ amalgamator may only break apart these aggregates. In the past, it 


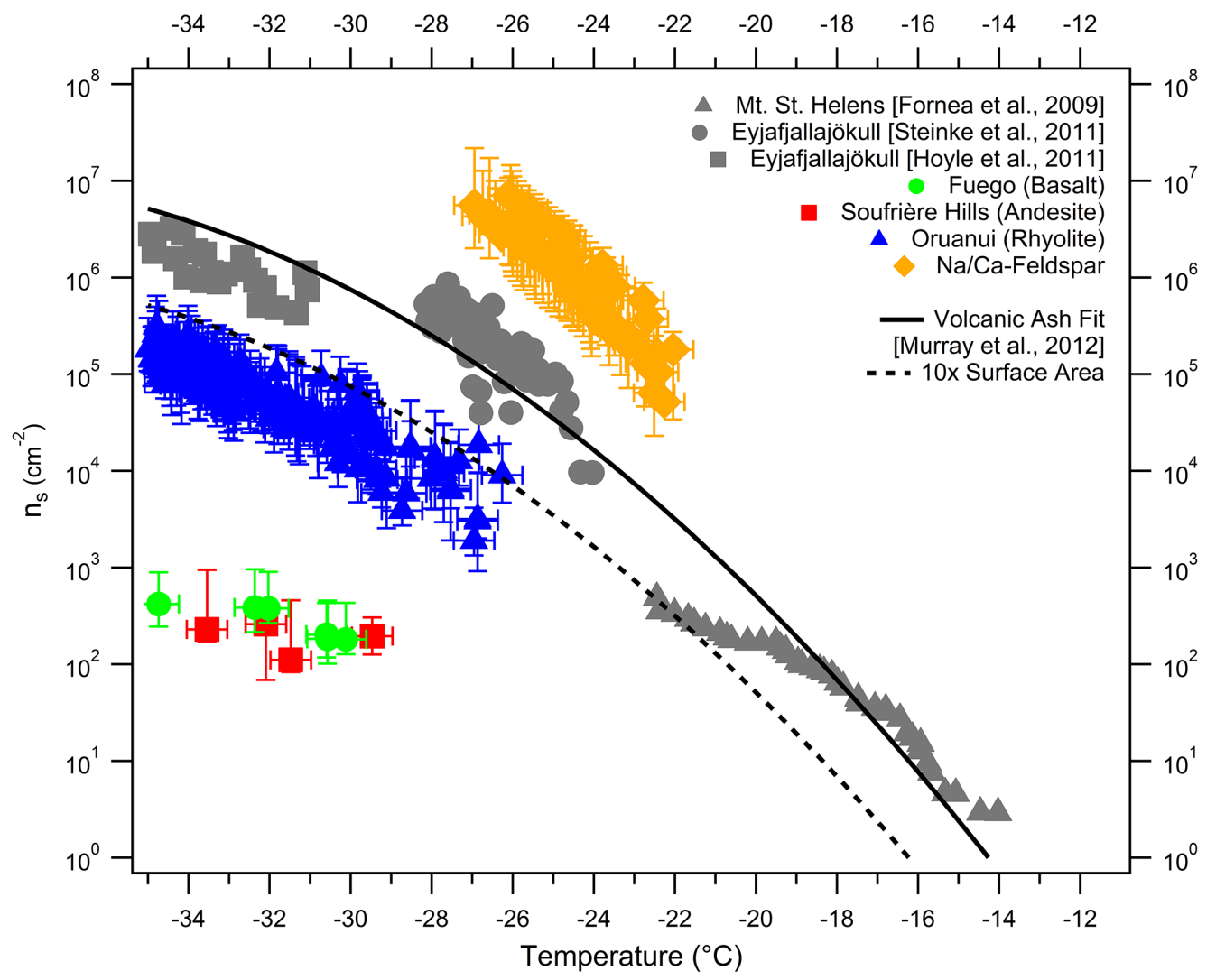

Figure 8. Ice nucleation active surface site densities as a function of temperature for Oruanui, Soufrière Hills, and Fuego ash and NIST SRM-99b soda feldspar. Also shown are $n_{\mathrm{s}}$-values for previous studies (grey markers) on volcanic ash and a parameterization for those data (solid line, Murray et al., 2012). Additionally, a new parameterization has also been shown that assumes surface area of the volcanic to be 10 times greater than the original parameterization to account for the high porosity of volcanic ash (dashed line).

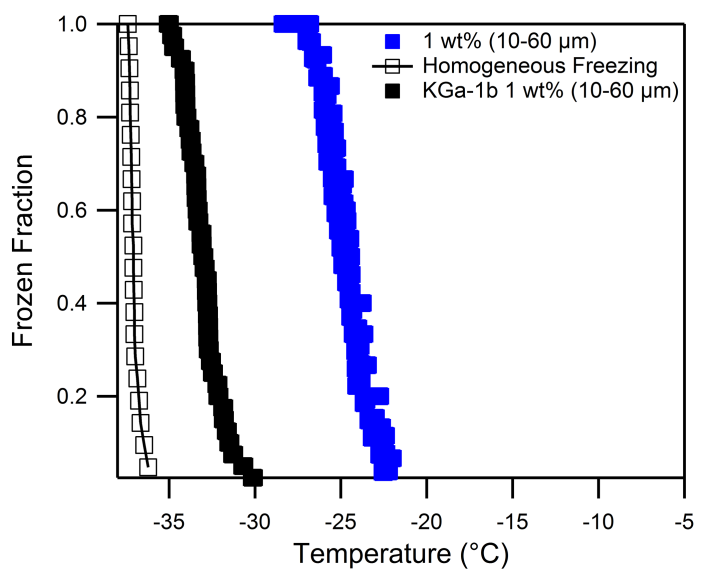

Figure 9. Frozen fraction curve for $1 \mathrm{wt} \% \mathrm{Na} / \mathrm{Ca}$ feldspar in 10$60 \mu \mathrm{m}$ droplets as a function of temperature.

has been shown that wet generation techniques can affect the hygroscopicity and cloud droplet formation ability of mineral dust (Sullivan et al., 2010; Garimella et al., 2014). Thus, allowing the ash samples to shake in solution for at least
$12 \mathrm{~h}$ prior to immersion freezing experiments could cause the dissolution/redistribution of active surface sites. This, however, is unlikely since this treatment was also conducted for kaolinite, which agrees with previous literature values of wet and dry generated KGa-1b (Pinti et al., 2012; Murray et al., 2011).

\section{Atmospheric implications}

Previously, it has been suggested that all volcanic ash has similar ice nucleation efficiency and may initiate ice below $250-260 \mathrm{~K}$, leading to an overseeding of ice in volcanic plumes (Durant et al., 2008). Since volcanic ash concentration in plumes can be up to $1000 \mathrm{~cm}^{-3}$, overseeding of ice could create a dearth of supercooled water droplets and shut down the Bergeon-Findeisen process, the process of ice crystal growth at the expense of supercooled liquid droplets in mixed-phase clouds. Thus, since particle growth would be reliant on collision processes, overseeding could retard or even prevent the development of precipitation in volcanic plumes. In this work, we have shown that three distinct types of volcanic ash have similar, efficient ice nucleation onsets in the 
deposition mode. It has been suggested that large amounts of water in pre-eruptive magma (up to $8 \%$ by mass) may render concentration of water in volcanic plumes greater than for typical thunderstorms (McNutt and Williams, 2010). Thus, the primary mode of ice nucleation in volcanic plumes may be immersion freezing. Unlike depositional freezing, the volcanic ash in this study did not possess the same ice nucleation efficiency in the immersion mode; indeed, both the Fuego and Soufrière Hills ash seem inactive in the immersion mode for droplets containing a surface area of ash equivalent to a spherical ash particle $\sim 60 \mu \mathrm{m}$ in diameter. Thus, our results indicate that some volcanic plumes may not be overseeded with ice. Indeed, this has been directly observed in some volcanic plumes such as the 17 September 1992 eruption of Mt Spurr, where remote sensing measurements showed that ash mass dominated over ice mass (Rose et al., 2001). The current study suggests that immersion freezing, and therefore overseeding, may be dictated by the differences in the mineralogy of the crystalline material found in volcanic ash. Thus, the identification and quantification of mineral phases in fine volcanic ash may be important to correctly predict the many processes in volcanic plumes that rely on ice and hydrometeor formation.

It has been shown that ash aggregation, which controls volcanic cloud dispersal, may be reliant on hydrometeor formation (Rose and Durant, 2011). If a volcanic plume is overseeded with ice, hydrometeor growth will be retarded, reducing aggregation and prolonging the lifetime and dispersal of the volcanic cloud (Brown et al., 2012). Correctly modeling volcanic cloud lifetimes and dispersal has important implications for both human health and aviation traffic. Volcanic lightning is another understudied process in volcanic plumes that is thought to be influenced by ice formation (McNutt and Williams, 2010). Volcanic lightning in high-altitude plumes is thought to be produced along a similar mechanism to thundercloud electrification and is important because it represents a hazard and contributes to the global electrification circuit. From this work, we show that some types of ash, depending on their mineralogy, may not initiate ice until the homogeneous freezing limit. Thus, previous thresholds of ice formation in volcanic plumes of 250-260 K may be overestimating the amount of volcanic lightning predicted in models.

Volcanic ash also has important climatic implications beyond the initial plume. Fine volcanic ash can stay suspended in the atmosphere for $24 \mathrm{~h}$ and travel $100 \mathrm{~s}$ to $1000 \mathrm{~s}$ of $\mathrm{km}$ (Brown et al., 2012). Previous work has shown that, while initial plumes contain large concentrations of water, volcanic clouds can dry out markedly within hours of entering the atmosphere (Schultz et al., 2006). Further, very fine ash can stay suspended much longer than $24 \mathrm{~h}$ and ash fall deposits may remain in local environments for years to decades and can be re-suspended due to human activity (Horwell and Baxter, 2006). In this work, we have shown that all three samples of volcanic ash had similar depositional ice nucleation efficiency $\left(S_{\text {ice }}=1.05 \pm 0.01\right)$, likely due to $\mathrm{Na} / \mathrm{Ca}$ feldspars, which is similar to previous findings on proxies of mineral dust. Thus, since depositional nucleation can occur at lower temperatures than immersion freezing, fine volcanic ash represents a potentially important source of global coldcloud ice nuclei. Indeed, in one study that took daily measurements of IN concentrations over a 2-year period from central Germany, the highest IN concentrations ever recorded coincided with backwards trajectories of the Eyjafjallajökull volcanic eruption in Iceland (Bingemer et al., 2012). In that same study, the IN concentrations in Israel, over $5000 \mathrm{~km}$ away from the source of the eruption, were determined for air-masses originated from the same volcanic eruption. The high IN concentrations found in those air masses were rivaled only during desert dust storms. Electron microscopy measurements confirmed that the most abundant IN in these air masses were volcanic ash. Furthermore, a study using polarization lidars at two central-European stations found a clear influence of volcanic ash on heterogeneous ice nucleation of tropospheric clouds. For example, in that study, all observed cloud layers with cloud top temperatures $<-15^{\circ} \mathrm{C}$ contained ice during the days following the April 2010 Eyjafjallajökull volcanic eruption (Seifert et al., 2011).

Our experimental results suggest that ice nucleation on fine volcanic ash may exert a non-negligible effect on volcanic plume lifetimes and dynamics as well as on global climate through the formation of cirrus clouds; however, volcanic ice nuclei are currently neglected in global climate models (Hoose et al., 2010). While previous works indicate that a simple parameterization for all ash types may be possible for the simplification of parameterizing immersion-mode volcanic ash ice nuclei in models (Murray et al., 2012), our results indicate that ash types could differ in ice nucleation properties, likely due to their mineralogy. Depositional nucleation on volcanic ash, however, may fall under such a parameterization since all three, distinct ash samples displayed similar depositional ice nucleation onsets to each other and to previous studies on ash from the Eyjafjallajökull volcano (Steinke et al., 2011; Hoyle et al., 2011).

Acknowledgements. This work was supported by the National Science Foundation under grant AGS1048536. We thank Bill Rose, Alexa Van Eaton, and the Montserrat Volcano Observatory for the utilized ash samples.

Edited by: H. Grothe 


\section{References}

Atkinson, J. D., Murray, B. J., Woodhouse, M. T., Whale, T. F., Baustian, K. J., Carslaw, K. S., Dobbie, S., O’Sullivan, D., and Malkin, T. L.: The importance of feldspar for ice nucleation by mineral dust in mixed-phase clouds, Nature, 498, 355-358, doi:10.1038/nature12278, 2013.

Baustian, K. J., Wise, M. E., and Tolbert, M. A.: Depositional ice nucleation on solid ammonium sulfate and glutaric acid particles, Atmos. Chem. Phys., 10, 2307-2317, doi:10.5194/acp-10-23072010, 2010.

Bingemer, H., Klein, H., Ebert, M., Haunold, W., Bundke, U., Herrmann, T., Kandler, K., Müller-Ebert, D., Weinbruch, S., Judt, A., Wéber, A., Nillius, B., Ardon-Dryer, K., Levin, Z., and Curtius, J.: Atmospheric ice nuclei in the Eyjafjallajökull volcanic ash plume, Atmos. Chem. Phys., 12, 857-867, doi:10.5194/acp12-857-2012, 2012.

Broadley, S. L., Murray, B. J., Herbert, R. J., Atkinson, J. D., Dobbie, S., Malkin, T. L., Condliffe, E., and Neve, L.: Immersion mode heterogeneous ice nucleation by an illite rich powder representative of atmospheric mineral dust, Atmos. Chem. Phys., 12, 287-307, doi:10.5194/acp-12-287-2012, 2012.

Brown, R. J., Bonadonna, C., and Durant, A. J.: A review of volcanic ash aggregation, Phys. Chem. Earth, 45-46, 65-78, doi:10.1016/j.pce.2011.11.001, 2012.

Curtis, D. B., Meland, B., Aycibin, M., Arnold, N. P., Grassian, V. H., Young, M. A., and Kleiber, P. D.: A laboratory investigation of light scattering from representative components of mineral dust aerosol at a wavelength of $550 \mathrm{~nm}$, J. Geophys. Res.-Atmos., 113, D08210, doi:10.1029/2007jd009387, 2008.

DeMott, P. J., Meyers, M. P., and Cotton, W. R.: Parameterization and impact of ice initiation processes relevant to numericalmodel simulations of cirrus clouds, J. Atmos. Sci., 51, 77-90, doi:10.1175/1520-0469(1994)051<0077:paioii> 2.0.co;2, 1994.

Durant, A. J., Shaw, R. A., Rose, W. I., Mi, Y., and Ernst, G. G. J.: Ice nucleation and overseeding of ice in volcanic clouds, J. Geophys. Res.-Atmos., 113, D09206, doi:10.1029/2007jd009064, 2008.

Durant, A. J., Bonadonna, C., and Horwell, C. J.: Atmospheric and Environmental Impact of Volcanic Particulates, Elements, 6, 235-240, doi:10.2113/gselements.6.4.235, 2010.

Everall, N. J.: Confocal Raman microscopy: common errors and artefacts, Analyst, 135, 2512-2522, doi:10.1039/c0an00371a, 2010.

Fornea, A. P., Brooks, S. D., Dooley, J. B., and Saha, A.: Heterogeneous freezing of ice on atmospheric aerosols containing ash, soot, and soil, J. Geophys. Res.-Atmos., 114, D13201, doi:10.1029/2009jd011958, 2009.

Garimella, S., Huang, Y.-W., Seewald, J. S., and Cziczo, D. J.: Cloud condensation nucleus activity comparison of dry- and wetgenerated mineral dust aerosol: the significance of soluble material, Atmos. Chem. Phys., 14, 6003-6019, doi:10.5194/acp-146003-2014, 2014.

Heiken, G.: Morphology and petrography of volcanic ashes, Geol. Soc. Am. Bull., 83, 1961-1988, doi:10.1130/00167606(1972)83[1961:mapova]2.0.co; 2, 1972.

Hiranuma, N., Hoffmann, N., Kiselev, A., Dreyer, A., Zhang, K., Kulkarni, G., Koop, T., and Möhler, O.: Influence of surface morphology on the immersion mode ice nucleation efficiency of hematite particles, Atmos. Chem. Phys., 14, 2315-2324, doi:10.5194/acp-14-2315-2014, 2014.

Hiranuma, N., Augustin-Bauditz, S., Bingemer, H., Budke, C., Curtius, J., Danielczok, A., Diehl, K., Dreischmeier, K., Ebert, M., Frank, F., Hoffmann, N., Kandler, K., Kiselev, A., Koop, T., Leisner, T., Möhler, O., Nillius, B., Peckhaus, A., Rose, D., Weinbruch, S., Wex, H., Boose, Y., DeMott, P. J., Hader, J. D., Hill, T. C. J., Kanji, Z. A., Kulkarni, G., Levin, E. J. T., McCluskey, C. S., Murakami, M., Murray, B. J., Niedermeier, D., Petters, M. D., O’Sullivan, D., Saito, A., Schill, G. P., Tajiri, T., Tolbert, M. A., Welti, A., Whale, T. F., Wright, T. P., and Yamashita, K.: A comprehensive laboratory study on the immersion freezing behavior of illite NX particles: a comparison of 17 ice nucleation measurement techniques, Atmos. Chem. Phys., 15, 2489-2518, doi:10.5194/acp-15-2489-2015, 2015.

Hobbs, P. V., Fullerton, C. M., and Bluhm, G. C.: Ice nucleus storms in Hawaii, Nat.-Phys. Sci., 230, 90-91, 1971.

Hoose, C. and Möhler, O.: Heterogeneous ice nucleation on atmospheric aerosols: a review of results from laboratory experiments, Atmos. Chem. Phys., 12, 9817-9854, doi:10.5194/acp-12-98172012, 2012.

Hoose, C., Kristjansson, J. E., Chen, J.-P., and Hazra, A.: A Classical-Theory-Based Parameterization of Heterogeneous Ice Nucleation by Mineral Dust, Soot, and Biological Particles in a Global Climate Model, J. Atmos. Sci., 67, 2483-2503, doi:10.1175/2010jas3425.1, 2010.

Horwell, C. J. and Baxter, P. J.: The respiratory health hazards of volcanic ash: a review for volcanic risk mitigation, B. Volcanol., 69, 1-24, doi:10.1007/s00445-006-0052-y, 2006.

Hoyle, C. R., Pinti, V., Welti, A., Zobrist, B., Marcolli, C., Luo, B., Höskuldsson, Á., Mattsson, H. B., Stetzer, O., Thorsteinsson, T., Larsen, G., and Peter, T.: Ice nucleation properties of volcanic ash from Eyjafjallajökull, Atmos. Chem. Phys., 11, 9911-9926, doi:10.5194/acp-11-9911-2011, 2011.

Hudson, P. K., Gibson, E. R., Young, M. A., Kleiber, P. D., and Grassian, V. H.: Coupled infrared extinction and size distribution measurements for several clay components of mineral dust aerosol, J. Geophys. Res.-Atmos., 113, D011201, doi:10.1029/2007jd008791, 2008.

Huneeus, N., Schulz, M., Balkanski, Y., Griesfeller, J., Prospero, J., Kinne, S., Bauer, S., Boucher, O., Chin, M., Dentener, F., Diehl, T., Easter, R., Fillmore, D., Ghan, S., Ginoux, P., Grini, A., Horowitz, L., Koch, D., Krol, M. C., Landing, W., Liu, X., Mahowald, N., Miller, R., Morcrette, J.-J., Myhre, G., Penner, J., Perlwitz, J., Stier, P., Takemura, T., and Zender, C. S.: Global dust model intercomparison in AeroCom phase I, Atmos. Chem. Phys., 11, 7781-7816, doi:10.5194/acp-11-7781-2011, 2011.

Isono, K., Komabayasi, M., and Ono, A.: Volcanoes as a source of atmospheric ice nuclei, Nature, 183, 317-318, doi:10.1038/183317a0, 1959.

Kolb, C. E., Cox, R. A., Abbatt, J. P. D., Ammann, M., Davis, E. J., Donaldson, D. J., Garrett, B. C., George, C., Griffiths, P. T., Hanson, D. R., Kulmala, M., McFiggans, G., Pöschl, U., Riipinen, I., Rossi, M. J., Rudich, Y., Wagner, P. E., Winkler, P. M., Worsnop, D. R., and O' Dowd, C. D.: An overview of current issues in the uptake of atmospheric trace gases by aerosols and clouds, Atmos. Chem. Phys., 10, 10561-10605, doi:10.5194/acp-10-10561-2010, 2010. 
Koop, T., Ng, H. P., Molina, L. T., and Molina, M. J.: A new optical technique to study aerosol phase transitions: The nucleation of ice from $\mathrm{H}_{2} \mathrm{SO}_{4}$ aerosols, J. Phys. Chem. A, 102, 8924-8931, doi:10.1021/jp9828078, 1998.

Koop, T., Luo, B. P., Tsias, A., and Peter, T.: Water activity as the determinant for homogeneous ice nucleation in aqueous solutions, Nature, 406, 611-614, doi:10.1038/35020537, 2000.

Langer, G., Garcia, C. J., Mendonca, B. G., Pueschel, R. F., and Fullerton, C. M.: Hawaiian volcanos-source of ice nuclei, J. Geophys. Res., 79, 873-875, doi:10.1029/JC079i006p00873, 1974.

Langmann, B.: On the Role of Climate Forcing by Volcanic Sulphate and Volcanic Ash, Adv. Meteorol., 2014, 340123, doi:10.1155/2014/340123, 2014.

McNutt, S. R. and Williams, E. R.: Volcanic lightning: global observations and constraints on source mechanisms, B. Volcanol., 72, 1153-1167, doi:10.1007/s00445-010-0393-4, 2010.

Murphy, D. M. and Koop, T.: Review of the vapour pressures of ice and supercooled water for atmospheric applications, Q. J. Roy. Meteorol. Soc., 131, 1539-1565, doi:10.1256/qj.04.94, 2005.

Murphy, M. D., Sparks, R. S. J., Barclay, J., Carroll, M. R., and Brewer, T. S.: Remobilization of andesite magma by intrusion of mafic magma at the Soufriere Hills Volcano, Montserrat, West Indies, J. Petrol., 41, 21-42, doi:10.1093/petrology/41.1.21, 2000.

Murray, B. J., Broadley, S. L., Wilson, T. W., Atkinson, J. D., and Wills, R. H.: Heterogeneous freezing of water droplets containing kaolinite particles, Atmos. Chem. Phys., 11, 4191-4207, doi:10.5194/acp-11-4191-2011, 2011.

Murray, B. J., O'Sullivan, D., Atkinson, J. D., and Webb, M. E.: Ice nucleation by particles immersed in supercooled cloud droplets, Chem. Soc. Rev., 41, 6519-6554, doi:10.1039/c2cs35200a, 2012.

Niemand, M., Moehler, O., Vogel, B., Vogel, H., Hoose, C., Connolly, P., Klein, H., Bingemer, H., DeMott, P., Skrotzki, J., and Leisner, T.: A Particle-Surface-Area-Based Parameterization of Immersion Freezing on Desert Dust Particles, J. Atmos. Sci., 69, 3077-3092, doi:10.1175/jas-d-11-0249.1, 2012.

Pinti, V., Marcolli, C., Zobrist, B., Hoyle, C. R., and Peter, T.: Ice nucleation efficiency of clay minerals in the immersion mode, Atmos. Chem. Phys., 12, 5859-5878, doi:10.5194/acp-12-58592012, 2012.

Robock, A.: Climatic Impact of Volcanic Emissions, in: The State of the Planet: Frontiers and Challenges in Geophysics, American Geophysical Union, Washington, D.C., 125-134, 2004.

Rose, W. I. and Durant, A. J.: Fate of volcanic ash: Aggregation and fallout, Geology, 39, 895-896, doi:10.1130/focus092011.1, 2011.

Rose, W. I., Anderson, A. T., Woodruff, L. G., and Bonis, S. B.: October 1974 basaltic tephra from fuego volcano-description and history of magma body, J. Volcanol. Geoth. Res., 4, 3-53, doi:10.1016/0377-0273(78)90027-6, 1978.

Rose, W. I., Bluth, G. J. S., Schneider, D. J., Ernst, G. G. J., Riley, C. M., Henderson, L. J., and McGimsey, R. G.: Observations of volcanic clouds in their first few days of atmospheric residence: The 1992 eruptions of Crater Peak, Mount Spurr volcano, Alaska, J. Geol., 109, 677-694, doi:10.1086/323189, 2001.

Schill, G. P. and Tolbert, M. A.: Heterogeneous ice nucleation on phase-separated organic-sulfate particles: effect of liquid vs. glassy coatings, Atmos. Chem. Phys., 13, 4681-4695, doi:10.5194/acp-13-4681-2013, 2013.

Schnell, R. C. and Delany, A. C.: Airborne ice nuclei near an active volcano, Nature, 264, 535-536, doi:10.1038/264535a0, 1976.

Schultz, D. M., Kanak, K. M., Straka, J. M., Trapp, R. J., Gordon, B. A., Zrnic, D. S., Bryan, G. H., Durant, A. J., Garrett, T. J., Klein, P. M., and Lilly, D. K.: The mysteries of mammatus clouds: Observations and formation mechanisms, J. Atmos. Sci., 63, 24092435, doi:10.1175/jas3758.1, 2006.

Seifert, P., Ansmann, A., Gross, S., Freudenthaler, V., Heinold, B., Hiebsch, A., Mattis, I., Schmidt, J., Schnell, F., Tesche, M., Wandinger, U., and Wiegner, M.: Ice formation in ashinfluenced clouds after the eruption of the Eyjafjallajokull volcano in April 2010, J. Geophys. Res.-Atmos., 116, D00U04, doi:10.1029/2011jd015702, 2011.

Sihvonen, S. K., Schill, G. P., Lyktey, N. A., Veghte, D. P., Tolbert, M. A., and Freedman, M. A.: Chemical and Physical Transformations of Aluminosilicate Clay Minerals Due to Acid Treatment and Consequences for Heterogeneous Ice Nucleation, J. Phys. Chem. A, 118, 8787-8796, doi:10.1021/jp504846g, 2014.

Small, C. and Naumann, T.: The global distribution of human population and recent volcanism, Environ. Hazards, 3, 93-109, doi:10.3763/ehaz.2001.0309, 2001.

Steinke, I., Möhler, O., Kiselev, A., Niemand, M., Saathoff, H., Schnaiter, M., Skrotzki, J., Hoose, C., and Leisner, T.: Ice nucleation properties of fine ash particles from the Eyjafjallajökull eruption in April 2010, Atmos. Chem. Phys., 11, 12945-12958, doi:10.5194/acp-11-12945-2011, 2011.

Sullivan, R. C., Moore, M. J. K., Petters, M. D., Kreidenweis, S. M., Qafoku, O., Laskin, A., Roberts, G. C., and Prather, K. A.: Impact of Particle Generation Method on the Apparent Hygroscopicity of Insoluble Mineral Particles, Aerosol Sci. Technol., 44, 830-846, doi:10.1080/02786826.2010.497514, 2010.

Todoli, J. L. and Mermet, J. M.: Liquid Sample Introduction in ICP Spectrometry: A Practical Guide, Elsevier Science, the Netherlands, 2011.

Vali, G.: Freezing rate due to heterogeneous nucleation, J. Atmos. Sci., 51, 1843-1856, doi:10.1175/15200469(1994)051<1843:frdthn>2.0.co;2, 1994.

Vali, G.: Repeatability and randomness in heterogeneous freezing nucleation, Atmos. Chem. Phys., 8, 5017-5031, doi:10.5194/acp-8-5017-2008, 2008.

Vali, G. and Stansbury, E. J.: Time-dependent characteristics of heterogeneous nucleation of ice, Can. J. Phys., 44, 477-502, 1966.

Van Eaton, A. R., Muirhead, J. D., Wilson, C. J. N., and Cimarelli, C.: Growth of volcanic ash aggregates in the presence of liquid water and ice: an experimental approach, B. Volcanol., 74, 19631984, doi:10.1007/s00445-012-0634-9, 2012.

Wilson, C. J. N., Blake, S., Charlier, B. L. A., and Sutton, A. N.: The 26.5 ka Oruanui eruption, Taupo volcano, New Zealand: Development, characteristics and evacuation of a large rhyolitic magma body, J. Petrol., 47, 35-69, 2006.

Wise, M. E., Baustian, K. J., and Tolbert, M. A.: Internally mixed sulfate and organic particles as potential ice nuclei in the tropical tropopause region, P. Natl. Acad. Sci. USA, 107, 6693-6698, doi:10.1073/pnas.0913018107, 2010.

Witham, C. S., Oppenheimer, C., and Horwell, C. J.: Volcanic ash-leachates: a review and recommendations for sam- 
pling methods, J. Volcanol. Geoth. Res., 141, 299-326, doi:10.1016/j.jvolgeores.2004.11.010, 2005.

Yakobi-Hancock, J. D., Ladino, L. A., and Abbatt, J. P. D.: Feldspar minerals as efficient deposition ice nuclei, Atmos. Chem. Phys., 13, 11175-11185, doi:10.5194/acp-13-11175-2013, 2013.
Zolles, T., Burkart, J., Häusler, T., Pummer, B., Hitzenberger, R., and Grothe, H.: Identification of Ice Nucleation Active Sites on Feldspar Dust Particles, J. Phys. Chem. A, 119, 2692-2700, doi:10.1021/jp509839x, 2015. 